IKONOMIKA: Jurnal Ekonomi dan Bisnis Islam

Volume 3, No. 2 (2018)

ISSN : 2527-3434 (PRINT) - ISSN: 2527-5I43 (ONLINE)

Page : $205-220$

\title{
Impact Of Indonesian Islamic Bank To Build Growth Premium Income Of Shari’a Insurance Company In Indonesia Market
}

\author{
Reza Ronaldo ${ }^{1}$, Maya Meilia ${ }^{2}$, Hasan Alaaraj ${ }^{3}$ \\ STEBI Lampung ${ }^{1,2}$, Lebanese International University ${ }^{3}$ \\ Rezaronaldo@Stebilampung.Ac.Id ${ }^{1}$, Maya@Stebilampung.Ac.Id ${ }^{2}$, hassan.aaraj@liu.edu.lb³
}

\begin{abstract}
In 2017 the Indonesian Islamic Bank contributes premium income to Sharia Insurance in Indonesia amounting to I.8 billion rupiah. There are 5 (five) Islamic Banks in Indonesia that contribute premiums to national Shari'a Insurance. The big five Islamic Banks in Indonesia are; Bank Mandiri Sharia (BMS), Bank Muamalat Indonesia (BMI), Bank Negara Indonesia Shari'a (BNIS), Bank Rakyat Indonesia Shari'a (BRIS) and Bank Mega Shari"a. With increasing income of the National Shari"a Bank, it is expected to have an increasingly income of Shari"a National. Indonesian Islamic Banks give significant contribution to the growth of Shari' a Insurance premiums in Indonesia. While other Shari' a financial instruments in Indonesia such as Shari'a BPR, Leasing Shari'a are not so large, so they have not provided significant premium contributions to National Shari"a Insurance. If other Islamic Financial Instruments can accelerate market share, then of course it will be able to provide additional premiums that are not small to Shari'a Insurance in Indonesia. This research is expected to be further developed in order to increase the income of Islamic banks in Indonesia while at the same time growing national Shari' a Insurance Premium Income.
\end{abstract}

Keywords : Islamic Bank, Sharia Insurance and Takaful.

\section{A. INTRODUCTION}

Indonesia as one of the major countries that has the majority of the population of Muslims is certainly a very good market opportunity for the growth of Islamic finance. At present Indonesia is a country with the world's largest Muslim population. Based on the data reported by The Pew Forum on Religion Public Life, a follower of Islam in Indonesia is 209.I million people or 87.2 
percent of the total population. That amount constituting I3.I percent of all Muslims in the world.

Adherents Islam in a country with the second largest population in the world reaches 176.4 million people or I4.4 percent of the total population. Total it constitutes II percent of the total number of adherents of Islam in the world. Islamic religion is concentrated in the Asia-Pacific region (62 percent). Others are in the Middle East and North Africa (20 percent), as well as Sub-Saharan Africa (I6 percent).

Muslim populationis also found in Europe (3 percent). Meanwhile the population of Islam in North America, Latin America and The Caribbean number is less than one percent.

What is Islamic Banking? Islamic banking, also known as non-interest banking, is a banking system that is based on the principles of Islamic, or Shari'a, law and guided by Islamic economics. Two fundamental principles of Islamic banking are the sharing of profit and loss and the prohibition of the collection and payment of interest by lenders and investors. Islamic law prohibits collecting interest or "riba".

Islamic banking is grounded in Shari'a or Islamic principles and all bank undertakings follow those Islamic morals. Islamic rules on transactions are called Fiqh al-Muamalat. Typically, financial transactions within Islamic banking are a culturally distinct form of ethical investing. For example, investments involving alcohol, gambling, pork, and other forbidden items is prohibited. There are over 300 hundred Islamic banks in over 5 I countries, including the United States.

The principles of Islamic Banking follow Sharia law, which is based on the Quran and the Hadist, the recorded sayings, and actions of the Prophet Muhammad. When more information or guidance is necessary, Islamic bankers turn to learned scholars or use independent reasoning based on scholarship and customs. The bankers also ensure their ideas do not deviate from the fundamental principles of the Quran.

The origin of Islamic banking dates back to the beginning of Islam in the seventh century. The Prophet Muhammad's first wife, Khadija, was a merchant. He acted as an agent for her business, using many of the same principles used in contemporary Islamic banking. In the Middle Ages, trade and business activity in the Muslim world relied on Islamic banking principles. These banking principles spread throughout Spain, the Mediterranean, and the Baltic States, arguably 
providing some of the basis for western banking principles. From the I960s to the I970s, Islamic banking resurfaced in the modern world.

\section{Background Islamic Bank in Indonesia.}

Banking deregulation in Indonesia began since I983. In that year, Bank Indonesia as Central Bank of Republic Indonesia provided flexibility to banks to set interest rates. The government hopes that the banking deregulation policy will create a more efficient and strong banking environment in supporting the economy. In 1983 the Indonesian government had planned to implement a "profit sharing system" in credit which was a concept of Islamic banking.

In 1988, the Government issued a Banking Deregulation Policy Package 1988 (Pakto 88) which opened the widest opportunity for banking business to be opened as widely as possible to support development (banking system liberalization). Although more conventional banks were established, several regional banking businesses based on Shari' a also began to emerge.

The initiative to establish an Indonesian Islamic bank began in I980 through discussions on Islamic banks as a pillar of Islamic economics. As a trial, the idea of Islamic banking was practiced on a relatively limited scale including in Bandung (Bait At-Tamwil Salman ITB) and in Jakarta (Koperasi Ridho Gusti).

In I990, the Indonesian Ulama Council (MUI) formed a working group to establish Islamic Banks in Indonesia. On August 18-20, I990, the Indonesian Ulema Council (MUI) held a bank and banking interest workshop in Cisarua, Bogor, West Java.

The results of the workshop were then discussed in more depth at the Majelis Ulama Indonesia (MUI) IV National Conference in Jakarta August 22-25, 1990, which resulted in the mandate for the establishment of a working group to establish Islamic banks in Indonesia. The intended working group is called the MUI Banking Team with the task of approaching and consulting with all parties involved.

As a result of the work of the MUI Banking Team, the first Islamic bank in Indonesia was established, namely PT. Bank Muamalat Indonesia (BMI), which was established on November I, I991. Since May I, I992, the BMI officially operated with an initial capital of Rp. 382,000,00. At the beginning of its operation, the existence of Islamic banks has not yet obtained optimal attention in the national banking sector. The bank operating system that uses the Sharia system, at that time was only accommodated in one of the verses about "Banks with profit sharing systems" in Indonesian law by Undang Undang No. 7/I992; 
without details of the principles of Shari'a law and the types of businesses that are permitted.

In 1998, the government and the People's Representative Council made improvements to Indonesian Law (Undang Undang) No. 7/1992 became Indonesian Law, Undang Undang No. I0 / 1998, which explicitly explained that there were two systems in banking in the country (dual banking system), namely the conventional banking system and the Islamic banking system.

This opportunity was warmly welcomed by the banking community, which was marked by the establishment of several other Islamic Banks, namely

\section{Bank IFI, Bank Shari’a Mandiri, Bank Niaga, BTN, Bank Mega, BRI, Bukopin, BPD Jabar and BPD Aceh etc.}

Ratification of several legislative products that provide legal certainty and enhance the activities of the Shari'a financial market, such as:

$\checkmark$ Undang-Undang (Indonesia Law) No.2I/2008 concerning Shari’a Banking;

$\checkmark$ Undang-Undang (Indonesian Law) No. 19/2008 concerning State Shari’a Securities (sukuk);

$\checkmark$ Undang Undang (Indonesian Law) No.4 2 of 2009 concerning the Third Amendment to Law No.8 of 1983 concerning VAT on Goods and Services.

With the enactment of Indonesian Law No. 21/2008 concerning Sharia Banking, which was issued on July I6, 2008, the development of the national Shari' a banking industry increasingly has an adequate legal basis and will encourage its growth faster. With the progress of its impressive development, which achieved an average asset growth of more than $65 \%$ per year in the last five years, it is expected that the role of the Islamic banking industry in supporting the national economy will be increasingly significant.

Right now, Indonesia having I2Islamic Bank or BUS (Bank Umum Syariá)and 22 UUS (Islamic Bank have not spin off yet) and I62 BPR Syariá (BPRS) in less than ten years (2009-2015).

The development of the Islamic banking system in Indonesia began, in two decades the development of national Islamic finance, there has been a lot of progress, both from institutional aspects and supporting infrastructure, regulation and supervision systems, as well as public awareness and literacy of Shari'a financial services. Our Islamic financial system is one of the best and most comprehensive systems that is internationally recognized.

As of June 20I5, the Shari'a banking industry consisted of I2 Shari'a Commercial Banks, 22 Shari’a Business Units owned by Conventional Commercial 
Banks and I62 BPRS with total assets of Rp. 273,494 Trillion with a market share of $4.6 \mathrm{I} \%$. Especially for the DKI Jakarta Province, gross total assets, financing, and Third Party Funds (BUS and UUS) are Rp. 20I,397 Trillion, Rp. 85,4I0 Trillion and Rp. II0,509 Trillion. At the end of 2013, banking regulation and supervision function.

5 (five) Best Ranks of Islamic Banks in Indonesia 2017 are;

a. Bank Shari'a Mandiri.

The best Shari'a Bank in Indonesia is Bank Shari'a Mandiri. The bank, which was established in 20II, introduced Shari'a-based products. Actually, there is no difference between the types of Bank Sharia Mandiri and Bank Mandiri. The thing that distinguishes it is the system and product base which is Sharia.

b. Bank Muamalat Indonesia(BMI).

Bank Muamalat Indonesia is ranked second as the best Islamic Bank in Indonesia. Not far from BSM, Bank Muamalat Indonesia has been established in 20I I. This Sharia Bank offers a savings and loan system to the community with the Islamic banking system. No doubt, there have been many customers collected at Bank Muamalat Indonesia.

c. BRI Shari'a.

Unlike a year with Bank Shari'a Mandiri and Bank Muamalat Indonesia, BRI Shari'a Bank has been established since 20I0. With more than 74 branch offices throughout Indonesia, BRI Shari'a Bank has gained a position in the heart of the community at large. Similar to other types of Islamic banks, BRI Shari’a Bank also offers various types of Islamic finance.

d. BNI Shari'a.

Bank BNI Shari'a has the fourth best position in Indonesia. The products offered from Bank BNI Shari'a are also very attractive, namely gold installment loans, mortgage loans, and other types of Islamic savings.

e. Bank Mega Shari'a.

For the position of the top five of the Best Shari'a Bank rankings in Indonesia, Mega Shari'a Bank should be a choice. Lately, there have been a lot of people who use Bank Mega Shari'a. One of them is for Hajj Savings products. Of course this product is very beneficial for those of you who are still confused to bestow savings to fulfill your pillars of Islam. Of the five best types of Islamic banks in Indonesia, there is no harm in giving up your finances to Bank Mega 
Shari'a which will fulfill your financial needs and desires in accordance with the applicable Shari'a system.

\section{Moelims Population in Indonesia.}

Indonesia as one of the major countries that has the majority of the population of Muslims is certainly a very good market opportunity for the growth of Islamic finance. At present Indonesia is a country with the world's largest Muslim population. Based on the data reported by The Pew Forum on Religion Public Life, a follower of Islam in Indonesia, is 209.I million people or 87.2 percent of the total population. That amount constituting I3.I percent of all Muslims in the world. The second largest Muslim country is India.

Adherents Islam in a country with the second largest population in the world reaches 176.4 million people or I4.4 percent of the total population. Total it constitutes II percent of the total number of adherents of Islam in the world. Islamic religion is concentrated in the Asia-Pacific region (62 percent). Others are in the Middle East and North Africa (20 percent), as well as Sub-Saharan Africa (I6 percent).

The size of Muslims in Indonesia is predicted to bring good development to the improvement of the Shari'a banking business and certainly will bring a significant influence to the development of Shariá Insurance in Indonesia

\section{Figure I}

\section{Ten countries with the largest Islamic population in the world}

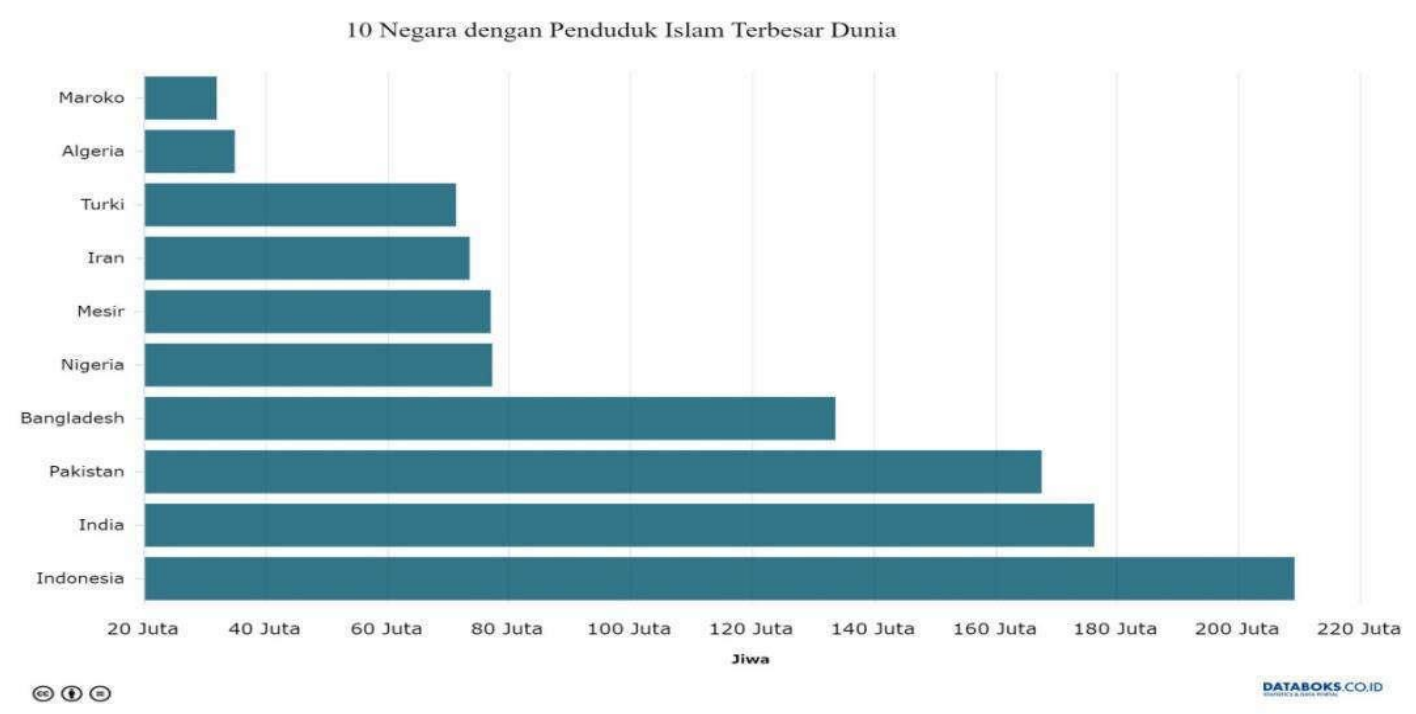




\section{B. THEORITICAL}

M, Kabir Hasan, Phd, in Handbook of Islamic Banking (20I3) said that The Theory of Profit Sharingneed for a rapprochement between theory and practice in Islamic finance.Bankers and policymakers have focused on the problem that, despite several years ofexperience by now in the countries that have adopted Islamic banking, it is still the casethat a high percentage of the assets of the domestic banking system have remained concentrated in short-term or trade-related modes of financing rather than in the more bonafide modes of musharaka and mudaraba.

Musharaka literally means "sharing" and is a form of joint enterprise through which the partners share their profit according to a predetermined ratio, as with mudaraba. But musharaka is different from mudaraba because it requires losses to be strictly sharedaccording to the proportion of the contributions. This arrangement accommodates partners who wish to pool their financial resources to undertake a commercial transaction.

Murabaha is defined as a contract of sale in which a customer requests the Islamic bank to buy goods from a supplier and resell them to the customer at the original purchase price plus expenses and a negotiated profit, on agreed terms. This financial structure is one of the most commonly used methods by Islamic banks and financial institutions. In fact, $70 \%$ of Islamic transactions worldwide are conducted through the murabaha structure

The weaker Islamic modes are permissible underthe sharia, but unfortunately they do not provide the same advantages as the profitsharing modes, including incentives for financing longer-term investment projects andimproved risk management.All banking and finance transactions have to be in compliance with Islamic law, or "Shari"a-compliant". Shari'a is derived from the Qur'an (the holy book of Muslims), the sayings of the Prophet Muhammad (the last messenger to convey the message of Islam) and Islamic schools of law.The Qur'an itself contains only a few verses of legal significance and it was really Islamic jurists who developed legal tools such as:

- Qiyas: literally, this means analogy and is a process whereby a ruling from another case is extended to reach a conclusion - similar to the use of precedent in the Western legal system;

- Ijma or consensus, which is similar to the concept of public consultation and is based on a saying of the Prophet Muhammad: "My community shall never agree on error";

$\checkmark$ 'urf: custom;

$\checkmark$ ijtihad: independent thinking; 


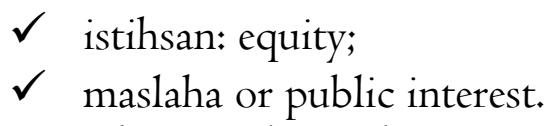

These tools combine to make up Islamic jurisprudence (figh). They were developed three centuries after the death of the Prophet Muhammad and led to the reation of four major schools of Islamic law (Maliki, Hanafi, Hanbali, and Shafii i).

Islamic commercial system based Islamic law governing commercial transactions (mu'amalat) has major differences to the conventional commercial system.First, and most importantly, Islamic finance is asset-based as opposed to conventional finance which is debt-based. This means that each transaction has to be tied to a "tangible, identifiable underlying asset". According to Shari' a law, you are allowed to buy or sell items with payment deferred and the resultant debt is treated as "amount receivable" by the creditor. This can be contrasted to a lender in conventional finance where the focus is on the debt arising from the transaction and the continuing service of the debt for financial gain.

Second, and also importantly, all forms of interest (riba) are strictly forbidden according to the major schools of Islamic law.Third, Islamic banking prohibits uncertainty (gharar) and the terms and conditions of any risk flowing from transactions must be clearly understood by the parties to any transaction. This means that the sale of probable items with uncertain existence cannot form the subject of a contract under Shari'a law. Traditional examples provided by Islamic scholars includedthe sale of fish in the sea, or unborn animals.

Contemporary examples of such a prohibition include trading in futures and derivatives and buying insurance. Fourth, it is also important that money should be invested only in industries that are acceptable to Islamic law. Investment in the alcohol, pornographic, gambling and porkindustries is strictly forbidden.

\section{What is Islamic Insurance or Takaful Insurance?}

What is Islamic Insurance or Takaful ? Takaful is a type of Islamic insurance, where members contribute money into a pool system in order to guarantee each other against loss or damage. Takaful-branded insurance is based on sharia, Islamic religiouslaw, and explains how it is the responsibility of individuals to cooperate and protect each other.

Takaful insurance companies were introduced as an alternative to commercial insurance companies, which are seen as violating Islamic restrictions on riba (interest), al-maisir (gambling), and al-gharar (uncertainty) principles, and outlawed in sharia.Takaful works by all parties (policyholders).

All parties in takaful arrangement agree to guarantee each other and make contributions to a mutual fund, or pool, instead of paying premiums. The pool of 
collected contributions creates the takaful fund. The amount of contribution that each participant makes is based on the type of coverage they require and their personal circumstances. As in conventional insurance, a takaful contract specifies the nature of the risk and time period of coverage.

The takaful fund is managed and administered on behalf of the participants by a takaful operator, who charges an agreed-upon fee to cover costs. Much like a conventional insurance company, costs include sales and marketing, underwriting, and claims management.

If claims happened, all participants are paid out of the takaful fund and any remaining surpluses, after making provisions for the likely cost of future claims and other reserves, belong to the participants in the fund, not the takaful operator.

Those funds may be distributed to the participants in the form of cash dividends or distributions or via a reduction in future contributions. To operate takaful insurance company, must be operation by takaful principles are:

- It must operate according to Islamic co-operative principles.

- A reinsurance commission may be paid out to, or received from, only Islamic insurance and reinsurance companies.

- The insurance company must maintain two separate funds: a participants/policyholders' fund and a shareholders' fund.

\section{Differences basis between Islamic Insurance and Conventional Insurance.}

Most of Ulama Islam has concluded that conventional insurance is unacceptable in Islamic business because conventional insurance does not conform with sharia for the following reasons:

- Conventional insurance includes an element of al-gharar (uncertainty).

- Conventional insurance is based on the concept and practice of charging interest. Islamic insurance, on the other hand, is based on tabarru, where a portion of the contributions made by participants is treated as a donation.

- Policyholders in takaful insurance are usually referred to as participants meanwhile in conventional insurance, policyholders as the Insured.

\section{METHODOLOGY}

The research methodology used in writing of this article is done by comparing the data of Islamic banking in Indonesia during 2016 and 2017 and then compared to data on Islamic insurance premium income in Indonesia during 2016 and 2017.The data was obtained from an official report released by the Financial Services Authority (OJK) and data obtained from Perasuransi Statistics in Indonesia 2018. 
Impact Of Indonesian Islamic Bank To Build Growth Premium Income Of Shari'a

Insurance Company In Indonesia Market

Reza Ronaldo ${ }^{1}$, Maya Meilia ${ }^{2}$, Hasan Alaaraj ${ }^{3}$

Author used Smart Partial Lease Square (SPLS) version 3.2.8 to see impact between Islamic Bank to Sharia Insurance and how big Trust and comfort the customer of Islamic Bank and direct impact of Islamic Bank to make growth income of shariá Insurance. Concept Model and Result of calculation by Smart PLS as follows:

\section{Figure 2}

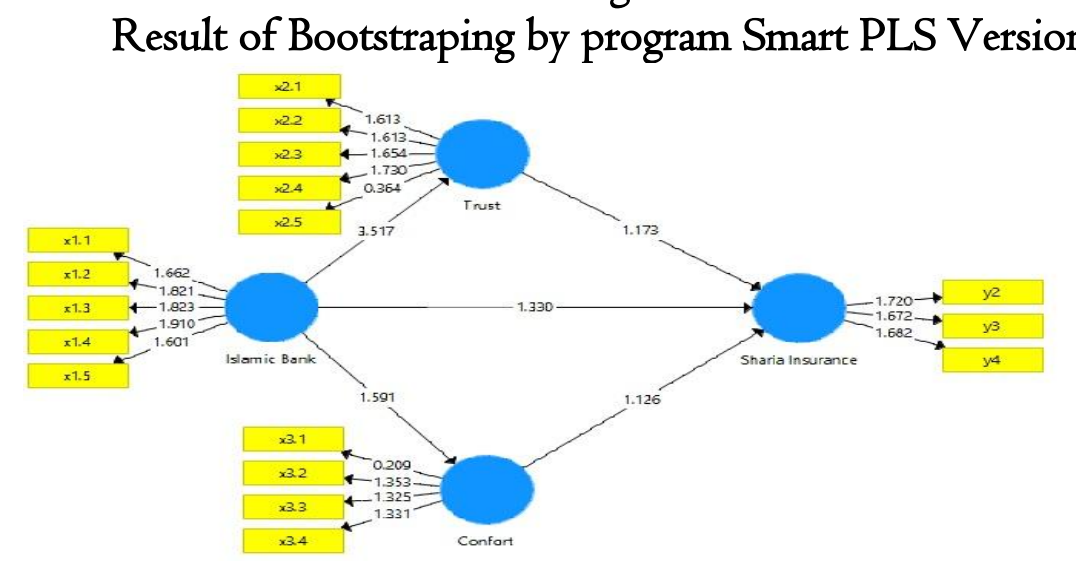

Figure 3.

List of Premium Income of Shari'a Company in Indonesia 2016

\begin{tabular}{|c|c|c|c|}
\hline NO. & NAMA PERUSAHAAN & $\begin{array}{c}\text { KONTRIBUSI BRUTO } \\
\text { (Rp. 000) }\end{array}$ & $\begin{array}{c}\text { MARKET SHARE } \\
(\%)\end{array}$ \\
\hline 1 & PT ASURANSI ASTRA BUANA & $447,954,000.00$ & $23.16 \%$ \\
\hline 2 & PT ASURANSI ADIRA DINAMIKA & $285,944,000.00$ & $14.79 \%$ \\
\hline 3 & PT ASURANSI RAMAYANA & $232,455,000.00$ & $12.02 \%$ \\
\hline 4 & PT ASURANSI BANGUN ASKRIDA & $220,507,000.00$ & $11.40 \%$ \\
\hline 5 & PT. ASURANSI JASINDO SYARIAH * & $129,523,000.00$ & $6.70 \%$ \\
\hline 6 & PT ASURANSI SINAR MAS & $104,621,000.00$ & $5.41 \%$ \\
\hline 7 & PT. ASURANSI CHUBB SYARIAH INDONESIA * & $81,666,000.00$ & $4.22 \%$ \\
\hline 8 & PT. ASURANSI TAKAFUL UMUM * & $73,419,000.00$ & $3.80 \%$ \\
\hline 9 & PT ASURANSI BINTANG TBK & $58,579,040.00$ & $3.03 \%$ \\
\hline 10 & PT ASURANSI TRI PAKARTA & $45,711,000.00$ & $2.36 \%$ \\
\hline 11 & PT ASURANSI UMUM MEGA & $42,346,000.00$ & $2.19 \%$ \\
\hline 12 & PT ASURANSI UMU BUMIPUTRAMUDA & $41,109,000.00$ & $2.13 \%$ \\
\hline 13 & PT ASURANSI CENTRAL ASIA & $40,349,000.00$ & $2.09 \%$ \\
\hline 14 & PT ASURANSI WAHANATATA & $23,674,000.00$ & $1.22 \%$ \\
\hline 15 & PT PAN PASIFIC INSURANCE & $21,628,000.00$ & $1.12 \%$ \\
\hline 16 & PT ASURANSI BRINS & $13,319,000.00$ & $0.69 \%$ \\
\hline 17 & PT ASURANSI ASEI INDONESIA & $13,099,000.00$ & $0.68 \%$ \\
\hline 18 & PT. ASURANSI SONWELIS TAKAFUL * & $13,014,450.00$ & $0.67 \%$ \\
\hline 19 & PT TUGU PRATAMA INDONESIA & $12,501,000.00$ & $0.65 \%$ \\
\hline 20 & PT ASURANSI STACO MANDIRI & $12,175,000.00$ & $0.63 \%$ \\
\hline 21 & OTHERS & $20,238,000.00$ & $1.05 \%$ \\
\hline \multicolumn{2}{|r|}{ TOTAL KONTRIBUSI INDUSTRI AS.UMUM SYARIAH } & $1,933,831,490.00$ & $100.00 \%$ \\
\hline
\end{tabular}

Source : Insurance Magazie Research Institute / Lembaga Riset Media Asuransi (LRMA) 
The data above is the result of the study of the Insurance Magazine Research Institute (LRMA) in 2016. The combined total of takaful premium income is I.93 Trillion Rupiah.

The type of Shari'a Insurance that dominates premium income is Motor Vehicle Insurance, Property Insurance and Marine Hull Insurance. Other types of insurance that have the potential to generate premiums in the future are credit life insurance.

There are 6 (six) Shari'a Insurance in Indonesia which dominate the sharia insurance market share in 2016, namely:Astra Buana Syariah Insurance 23.6\%, Adira Syariah Insurance I4.79\%, Ramayana Syariah I2.02\%, Bangun Askrida Insurance II.40\%, Jasindo Syariah Insurance 6.7\%, Sinarmas Syariah $5.4 \mathrm{I} \%$.

\section{RESULTS AND DISCUSSION}

After testing through Smart PLS, it was concluded that the increase in Insurance Sharia premium income in Indonesia was significantly influenced by revenue growth from the national Sharia Bank which currently has 22 Bank Umum Shari’a (BUS), 22 Unit Usaha Shari'a(UUS) and I63 BPRShari’a (BPRS).

The Smart PLS results show that Islamic Banks in Indonesia have an influence of I,394 on Sharia Insurance in Indonesia. This value is still above the significant level which is equal to I.59I so that it can be said that the Sharia Bank significantly provides a very dominant influence on the growth of Shari'a Insurance in Indonesia.

Indonesian society or the customers are very trusting and comfortable with the Shari'a Bank because the majority of the Indonesian population is Muslim. This is evidenced by the results of Smart PLS calculations which show 3,5I7 for Trusts and I,59I for Comfort of the customer to Shari'a Banks.

Convincingly, in fact it can be proven that the Indonesian people believe and are comfortable with Bank Shari'a.

Result calculation for I00 of customers Trust to Sharia Insurance I,I73 it's mean Significant and Comfort to Shari'a Insurance I,I26 it's higher than I, I6 value of significant level meaning peoples in Indonesia Comfort with Shariá Insurance.

Similarly, it can be concluded conclusively from the facts and data that the Indonesian people began to believe in Shari'a insurance even though the results were not as large as the results of trust and comfort for Bank Shari'a. 
Impact Of Indonesian Islamic Bank To Build Growth Premium Income Of Shari'a

Insurance Company In Indonesia Market

Reza Ronaldo ${ }^{1}$, Maya Meilia ${ }^{2}$, Hasan Alaaraj ${ }^{3}$

Income of national Islamic bank income in 2016 reaches 27.2 Trillion Rupiah, in fact it can provide premium income of 1.93 Trillion Rupiah to all Shari'a Insurance companies. When total income from Indonesian Islamic banking in 2017 reaches 30.8 Trillion Rupiah, found that Shari' a national banks, able to contribute income premium to national shari'a insurance of 2.34 Trillion Rupiah.

From the realization of premium income in 2016 and 2017, the facts we took the conclusions that the greater the exposure of Islamic banking in Indonesia will have a positive impact on the acquisition of Islamic insurance premium income in Indonesia market.

The data above can also illustrate that when national Islamic banking income reaches 27.2 Trillion Rupiah, the acquisition of Islamic insurance premiums generates revenue of I.93 Trillion Rupiah.

Total income from Indonesian Islamic banking in 2017 reaches 30.8 Trillion Rupiah, able to contribute premium income to national Shari'a insurance of 2.34 Trillion Rupiah.

Premium income of Sharia in Indonesia is still dominated by Sharia insurance companies which are also players of Conventional General Insurance, namely; Asuransi Astra, Asuransi Adira, Asuransi Jasindo, Asuransi Sinasmas, Chubb Insurance and Asuransi Takaful.

Figure 4.

Market Share of Shari'a Insurance Company in Indonesia 2017

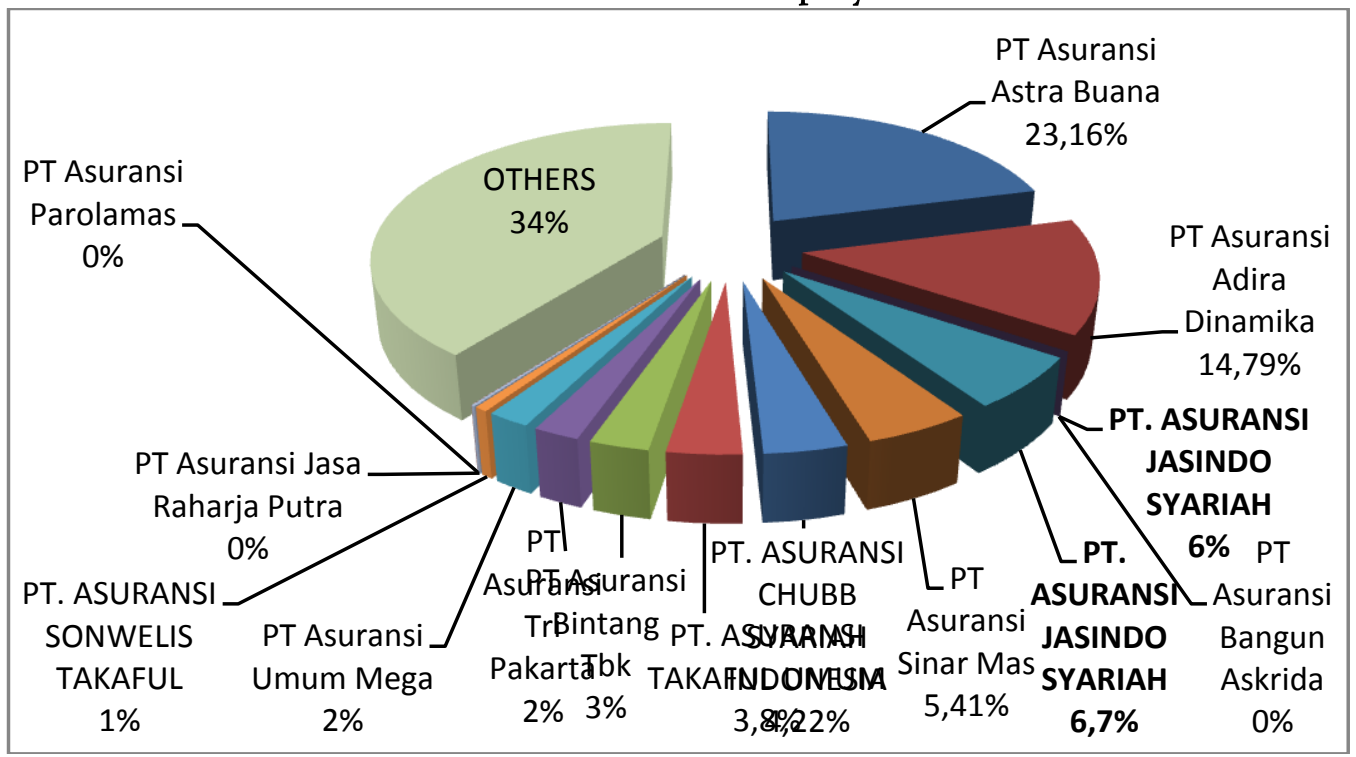

Source : Statistik Perasuransian OJK 2017 
Based on pie graphics I.4 above, it can be explained that the market leader of theShari' Insurance company in Indonesia 2016-20I7 is:Astra Buana Shari'a Insurance 23.16\%, Adira Shari'a Insurance I4.79\%, Asuransi Jasindo Shari'a 6.7\%, Sinar Mas Shari' a Insurance 5.41\%, Chubb Shari'a Insurance 4.22\%, General Takaful Insurance 3.8\%.

\section{Figure 5}

The Big Insurance Syaria Company in Indonesia 2016-2017

\begin{tabular}{|c|c|c|c|}
\hline 2016 & Market Share Premium Income & 2017 & Market Share Premium Income \\
\hline $\begin{array}{l}23.6 \% \\
14.79 \%\end{array}$ & $\begin{array}{l}\text { I. Astra Syaria Insurance } \\
\text { 2. Adira Syaria Insurance } \\
\text { 3. Ramayana Syaria } 12.02 \% \\
\text { 4. As. Bangun Askrida } \\
\text { 5. Jasindo Syariah Insurance } \\
\text { 6. Sinarmas Syariah } 5.41 \%\end{array}$ & $\begin{array}{l}23.16 \% \\
14.79 \% \\
6.7 \% \\
5.41 \% \\
4.22 \% \\
3.8 \%\end{array}$ & $\begin{array}{l}\text { 1. Astra Shari’a Insurance } \\
\text { 2. Adira Shari'a Insurance } \\
\text { 3. Asuransi Jasindo Shari'a } \\
\text { 4. Sinarmas Shari' a Insurance } \\
\text { 5. Chubb Shari'a Insurance } \\
\text { 6. General Takaful Insurance }\end{array}$ \\
\hline
\end{tabular}

(Data processed by Writer 2018)

Total income for National Islamic banking in 2017 is 30.8 Trillion Rupiah, able to contribute premium income to national Shari'a insurance of 2.34 Trillion Rupiah.

Premium income of Sharia in Indonesia is still dominated by Sharia insurance companies which are also players of Conventional General Insurance, namely; Asuransi Astra, Asuransi Adira, Asuransi Jasindo, Asuransi Sinasmas, Chubb Insurance and Asuransi Takaful.

\section{CONCLUSION}

Income of national Islamic bank income in 2016 reaches 27.2 Trillion Rupiah, in fact it can provide premium income of 1.93 Trillion Rupiah to all Shari'a Insurance companies. When total income from Indonesian Islamic banking in 2017 reaches 30.8 Trillion Rupiah, found that Sharia national banks, able to contribute income premium to national shari'a insurance of 2.34 Trillion Rupiah. 
From the realization of premium income in 2016 and 2017, the facts we took the conclusions that the greater the exposure of Islamic banking in Indonesia will have a positive impact on the acquisition of Islamic insurance premium income in Indonesia market.

After testing through Smart PLS, it was concluded that the increase in Insurance Sharia premium income in Indonesia was significantly influenced by revenue growth from the national Sharia Bank which currently has 22 BUS, 22 UUS and I63 BPRS.

The Smart PLS results show that Islamic Banks in Indonesia have an influence of I,394 on Sharia Insurance in Indonesia. This value is still above the significant level which is equal to I.64 so that it can be said that the Sharia Bank significantly provides a very dominant influence on the growth of Sharia Insurance in Indonesia.

Shari'a insurance companies in Indonesia are still very dependent on improving the Islamic banking business because other financial instruments have not yet received significant income. With the increasing income of national Islamic banking, it will certainly have an impact on Islamic insurance premium income in Indonesia.

It is the duty of all Islamic insurance industry players to always provide literacy and information to the public about the importance of insurance. Islamic banking, Shari'a insurance and OJK must continue to carry out a national campaign to develop insurance protection so that people can live more prosperously. If all Shari'a activities in Indonesia can continue to be developed, it is expected to have a positive impact on the welfare of economic muslims in Indonesia.

According to the fatwa of the National Sharia Council (DSN) as a regulator of the implementation of Islamic insurance in Indonesia, information is obtained that the sharia business is not specifically intended for Muslims. that means Non-Muslims can also use banking and Islamic insurance as long as they fulfill all the requirements and accept the sharia system.

With the development of sharia business in Indonesia, it is hoped that they will be able to develop Islamic economics and will further bring blessings to the entire Indonesian people and nation. 


\section{REFERENCES}

Ariff, Mohamed, ed. Islamic banking in Southeast Asia: Islam and the economic development of Southeast Asia. Institute of Southeast Asian Studies, I988.

Bhatty, Maria. Law Institute journal: the official organ of the Law Institute of Victoria 85, August 20II.

Grassa, Rihab. "Shari'a supervisory system in Islamic financial institutions: Newissues and challenges: A comparative analysis between Southeast Asia models andGCC models." Humanomics 29.4 (2013): 333-348.

Hamid, Mohamad Abdul, and Mohd Sukki Othman. "A study on the level of knowledge and understanding among Muslims towards the concepts, Arabic and Shari'a terms in Islamic Insurance (takaful)." European Journal of social sciences I0.3 (2009): 468-478.

Hasan, M. Kabir. Kayed, Rasem. N, Oeseni, Umar. A.," Ïntroduction to Islamic Banks \& Finance, Principle \& Practise". Pearson Education Limited. England. (2013).

Kader, Hale Abdul, Mike Adams, and Philip Hardwick. "The cost efficiency of takaful insurance companies." The Geneva Papers on Risk and Insurance-Issuesand Practice 35.I (2010): I6I-I8I.

Khorshid, Aly. Islamic insurance: A modern approach to Islamic banking.

Lewis, Mervyn K., and Latifa M. Algaoud. "Islamic banking." Books (200I).,Edward Elgar Publishing, number I 488.

Mansoor Khan, M., and M. Ishaq Bhatti. "Islamic banking and finance: on its way Psychology Press, 2004.

Purnamasari, F., \& Darmawan, A. (20I7). Islamic Banking and Empowerment of Small Medium Enterprise. Etikonomi, I6(2), 22I-230.

Rajhi, Wassim, and Slim A. Hassairi. "Islamic banks and financial stability: a comparative empirical analysis between MENA and southeast Asian countries." Région et développement 37.I (2013): I-3I.

Rosly, Saiful Azhar. Critical issues on Islamic banking and financial markets:Islamic economics, banking and finance, investments, Takaful and Financial Planning. Dinamas Publishing, 2005.Kuala Lumpur. ISBN 9834248903.

Suryanto, T. (20I7). Manajemen Laba Pada Bank Syariah Di Indonesia: Peran Komite Audit Dan Dewan Pengawas Syariah. KINERJA, I8(I), 90-I00. 
Impact Of Indonesian Islamic Bank To Build Growth Premium Income Of Shari'a

Insurance Company In Indonesia Market

Reza Ronaldo ${ }^{1}$, Maya Meilia ${ }^{2}$, Hasan Alaaraj ${ }^{3}$

Suryanto, T., \& Ridwansyah, R. (2016). The Shariah financial accounting standards: How they prevent fraud in Islamic Banking. European Research Studies, I9(4), I40.

to globalization." Managerial finance 34.10 (2008): 708-725.

Wahab, Abdul Rahim Abdul, Mervyn K. Lewis, and M. Kabir Hassan. "Islamic takaful: Business models, Shari' a concerns, and proposed solutions." ThunderbirdInternational Business Review 49.3 (2007): 37I-396.

Wilson, Rodney. Islamic business: theory and practice. Economist Intelligence Unit, 1985. 